\section{Effect of Mesquite on Physical and Chemical Properties of the Soil}

\author{
ARTHUR R. TIEDEMANN AND JAMES O. KLEMMEDSON
}

Highlight: Soil under the crown of mesquite trees was compared to soil from adjacent openings at three depths for several physical and chemical properties near Tucson, Ariz. Bulk density was lower in soil under mesquite but increased with depth in that location. Organic matter, total nitrogen, total sulfur, and total soluble salts were up to three times greater in the surface 0 to $4.5 \mathrm{~cm}$ of mesquite soil than in open soil but declined with increasing depth to levels approximately the same as in open soil. Total potassium was higher under mesquite but increased with depth. Total phosphorus and hydrogen ion concentrations were the same in soil under mesquite as in soil from open areas. Results suggest that mesquite trees function to improve soil conditions under their canopies by redistribution of nutrient ions from areas beyond the canopy to areas beneath the canopy. This process helps to explain the greater abundance and improved growth of perennial grasses observed under mesquite. It also helps to explain grazing patterns and responses on desert grassland.

Mesquite (Prosopis juliflora (Swartz.) DC.) is a native, deciduous, leguminous tree that has invaded vast areas of desert grassland range in the southwestern United States since the early 1900's. Because of a lateral root system that spreads to distances of $10 \mathrm{~m}$ or more (Kearney and Peebles, 1960), mesquite competes with perennial grasses for moisture in natural openings. This results in reduced forage production and increased soil erosion.

Effectiveness of mesquite in extraction of soil moisture and in competition with perennial grasses was demonstrated by Parker and Martin (1952). They found significant increases in moisture content of the upper $45 \mathrm{~cm}$ of soil at distances of 3,6 and $10 \mathrm{~m}$ from killed mesquite trees compared with live trees. Also, soil moisture was available for a longer period of time where mesquite trees were killed than where they were alive.

In comparison of surface soil properties between native desert grassland and invading mesquite stands, Paulsen (1950) found that native grassland soil had a more favorable physical regime and a higher nutrient capital than soil from the mesquite stands. However, an aspect of competition between mesquite trees and perennial grasses that has not been examined is the role of mesquite in altering physical and chemical properties of the

The authors are a range scientist at the Pacific Northwest Forest and Range Experiment Station, Forest Service, U. S. Department of Agriculture at Wenatchee, Washington; and a professor in the Department of Watershed professor in the Department of Watershed Tucson.

The paper is a contribution of Arizona Agricultural Experiment Station, Journal Article No. 1891, and the Pacific NW Forest and Range Exp. Sta.

Manuscript received January 5, 1972. soil of open areas where latcral roots extend and of areas directly beneath the canopy. Paulsen's measurements in the mesquite stand were confined to areas outside the perimeter of mesquite canopies. On the basis of knowledge gathered from other species, we expect absorption of soil moisture by lateral roots to be accompanied by absorption of soil nutrients. The nutrients are translocated to various parts of the tree, incorporated in plant biomass, and eventually returned to the soil as leaves, twigs, and other plant parts are shed. The bulk of this material falls directly beneath the mesquite canopy. This process presumably results in a more or less depleted nutrient regime, harsh physical condition of the soil in open areas, and a soil enriched by nutrients and organic matter beneath the canopy.

That such an alteration of the soil occurs is well documented in the literature (Fireman and Hayward, 1952; Zinke, 1962). In addition, mesquite trees may create a windbreak whereby loose organic debris swept from areas between trees is deposited beneath the mesquite canopies. The canopy then protects such material from removal by raindrop action and runoff. The magnitude of the alteration with respect to specific nutrients and species is not well known, nor is the effect on associated vegetation understood. For example, on some desert grassland areas, perennial grasses have been found to be more abundant under mesquite trees than in natural openings (Humphrey, 1962), but explanations for this association between grass and trees are wanting.

Measurements by Tiedemann (1970) show that production of perennial grasses under mesquite may exceed that in the open by five times $(1,200 \mathrm{~kg} / \mathrm{ha}$ vs. 225 $\mathrm{kg} / \mathrm{ha})$. Differences in soil moisture and soil temperature between areas under mesquite and open areas were not sufficient to account for this difference.

This study was conducted to assess the impact of mesquite trees on physical and chemical properties of the soil in natural openings and in areas under mesquite trees in an effort to explain the tree-grass association.

\section{Methods}

A 20-ha upland desert grassland site at the Santa Rita Experimental Range south of Tucson, Ariz., was selected for this study. Livestock had not grazed here since 1937. Mesquite is the dominant overstory vegetation of the area with catclaw (Acacia greggii Gray), and prickly pear and cholla (Opuntia sp.) comprising the majority of large shrubs. Burroweed (Aplopappus tenuisectus [Green] Blake) and zinnia (Zinnia pumila Gray) are the dominant halfshrubs. The most common perennial grasses are Arizona cottontop (Trichachne californica [Benth.] Chase), bush muhly (Muhlenbergia porteri Scribn.), plains bristlegrass (Setaria macrostachya H.B.K.), and black grama (Bouteloua eriopoda Torr.). Spiderling (Boerhaavia sp.) and portulaca (Portulaca sp.) are the most common forbs. Needle grama (Bouteloua aristidoides H.B.K.) is the predominant annual grass on the area. Soils are derived from alluvium of basic and acid igneous rocks and are coarse, deep, and well drained.

The study site was delineated into six blocks to account for differences in soils throughout the area. Three suitable trees were selected in each block, and of these, one was randomly chosen for sampling. Soil samples were collected $0.9 \mathrm{~m}$ due north and south of the trunk of each tree under the canopy and $6 \mathrm{~m}$ due north of the trunk in the open. Hereafter, these locations are referred to as north, south, and open, respectively. At each location, three cores and one loose sample were collected for the soil layers of 0 - to $4.5-\mathrm{cm}, 7.5-$ to $12-\mathrm{cm}$, and $15-$ to 19.5-cm.

Bulk density, soil texture, total nitrogen $(\mathrm{N})$ (exclusive of nitrate and nitrite $\mathrm{N}$ ), organic matter, hydrogen ion activity (pH), total soluble salts, and total phosphorus (P) were measured using procedures described by Black et al. (1965a and 1965b). Total sulfur (S) was measured by dry combustion and iodiometric titration (Tiedemann and Anderson, 1971 ) and total potassium (K) by multiple acid digestion and atomic absorption spectroscopy (Belt, 1967).

Analyses of variance were performed on the data. The design was split-plot with whole-plot treatments (location of 
soil sample in relation to the trees) occurring in blocks (trees). Soil depth was the split-plot factor. Depths were compared across locations using the Duncan Multiple Range test.

\section{Results}

Mesquite trees had significant impacts on the chemical and physical condition of the soil. Many characteristics examined varied with depth, but with the exception of $\mathrm{pH}$, change with depth was confined to locations under mesquite.

Bulk density in the surface 0 - to 4.5 $\mathrm{cm}$ soil layer under mesquite trees was significantly lower than in the open (Table 1). Bulk density increased significantly with depth under mesquite trees; no change with depth was noted in soils beyond the tree canopies. Soil texture did not change significantly among layers or locations. However, increasing amounts of gravel were found with depth on the north side of mesquite trees.

Organic matter, total $\mathrm{N}$, and total $\mathrm{S}$ in soil under mesquite were two to three times greater in the $0-$ to $4.5-\mathrm{cm}$ layer than in the two lower layers. There was no significant difference among soil layers in the open. Approximately three times more organic matter, total $\mathrm{N}$, and total $\mathrm{S}$ were found in the 0 - to $4.5-\mathrm{cm}$ layer under mesquite than in the same layer in the open. In addition, total $\mathrm{S}$ in the 7.5 to $12.0-\mathrm{cm}$ layer was significantly greater in both locations under mesquite than in the open.

In contrast to differences observed with total $\mathrm{N}$ and total $\mathrm{S}$, total $\mathrm{P}$ did not change significantly among locations regardless of the depth. There was, however, a significant decrease between the 0 to $4.5-\mathrm{cm}$ and $15-$ to $19.5-\mathrm{cm}$ layers on the north side of mesquite trees.

Location under the tree affected potassium levels. On the north side of mesquite trees, $\mathrm{K}$ increased significantly between the $0-$ to $4.5-\mathrm{cm}$ and the $15-$ to 19.5-cm layers. Total $\mathrm{K}$ was also higher at the latter depth on the north side of trees than on the south side or in the open. There was no change in total $\mathrm{K}$ among soil layers on either the south side of trees or in the open.

Soil reaction $(\mathrm{pH})$ increased significantly with depth in all three locations, but there were no differences among locations at any depth. Total soluble salts declined significantly with depth only on the north side of mesquite trees. Comparisons among locations showed that total soluble salts in the 0- to $4.5-\mathrm{cm}$ layer were significantly higher on the north side of mesquite than on the south and significantly higher on the south than in the open. No other layer comparisons among locations were significant.

\section{Discussion and Conclusions}

The presence of more N, K, S, soluble salts, and organic matter in soils under mesquite trees than between trees supports our hypothesis that mesquite trees enrich the soil under their canopies at the expense of the soil nutrient capital in the open areas. The mesquite tree seems to effectively redistribute nutrients which it has absorbed throughout its rooting volume to a zone principally beneath the tree canopy where the bulk of leaves, twigs, and other plant parts fall when shed by the tree. Garcia-Moya and McKell (1970) observed a similar pattern of enrichment of soil $\mathrm{N}$ under the canopies of other desert shrubs (Larrea, Acacia, and Cassia) while Zinke (1962) demonstrated the effect of shore pine (Pinus contorta) on the distribution pattern of several soil properties on a coastal dune in California.

Since about $95-98 \%$ of soil $\mathrm{N}$ and $\mathrm{S}$ is tied up in organic matter, we would expect most of the $\mathrm{N}$ and $\mathrm{S}$ to be located in the zone of concentration of organic matter and near the point of accrual of organic matter to the soil for these ecosystems. Our data indicate that the vertical concentration gradient for $\mathrm{N}$ and $S$ under mesquite is not as steep as that for organic matter. This is to be expected because colloidal organic matter (humus) does not readily move downward in calcareous soils. On the other hand, the soluble products of $\mathrm{N}$ and $\mathrm{S}$ mineralization (nitrate and sulfate) can be expected to be leached downward if their availability exceeds the demands of plants and microorganisms during periods of rainfall sufficient for leaching.

Despite the marked effect of mesquite on several soil nutrients and organic matter, its effect on soil $\mathrm{pH}$ was not significant over the lifetime of the tree ecosystems sampled. The change in $\mathrm{pH}$ with depth is characteristic for the Sonoita gravelly sandy loam soils and reflects leaching of carbonates from surface soils and precipitation deeper in the profile. There does seem to be a trend toward significantly lower $\mathrm{pH}$ on the north side of trees where $\mathrm{pH}$ reached 5.7 in the surface layer as opposed to 6.0 on the south side of trees and in the open. Perhaps heavier accumulations of litter on the north side of trees $(2,100 \mathrm{~kg} / \mathrm{ha}$ vs. $1,300 \mathrm{~kg} / \mathrm{ha}$ on the south) accounts for this trend. But acidity of percolates from this litter or throughfall are probably not sufficient for rapid changes in soil $\mathrm{pH}$. Leachates of mesquite litter soaked overnight with distilled water (ratio 1:8) produced a $\mathrm{pH}$ of 6.90 while those of an equal volume of fresh and dried leaves had $\mathrm{pH}$ values of 5.66 and 5.32 , respectively. Without soaking, the leachate from fresh leaves had a $\mathrm{pH}$ of 6.33. Comparison of these values with those from several other sources (Jenny, 1941) suggests that leachates of mesquite litter are characteristic of those from broad-leaved

Table 1. Physical and chemical properties of the soil at three depths for north and south locations under mesquite trees and in adjacent open areas. 1

\begin{tabular}{|c|c|c|c|c|c|c|c|c|c|}
\hline Location & $\begin{array}{r}\text { Depth } \\
(\mathrm{cm})\end{array}$ & $\begin{array}{c}\text { Bulk } \\
\text { density } \\
\left(\mathrm{g} / \mathrm{cm}^{3}\right)\end{array}$ & $\begin{array}{c}\text { Organic } \\
\text { matter } \\
(\%)\end{array}$ & $\mathrm{N}(\%)$ & $\mathrm{P}(\%)$ & $\mathrm{K}(\%)$ & $\mathrm{S}(\%)$ & $\mathrm{pH}$ & $\begin{array}{c}\text { Soluble } \\
\text { salts } \\
(\mathrm{mg} / 1)\end{array}$ \\
\hline North & $\begin{array}{l}0-4.5 \\
7.5-12.0 \\
15-19.5\end{array}$ & $\begin{array}{l}1.35^{\mathrm{a}} \\
1.54^{\mathrm{b}} \\
1.54^{\mathrm{b}}\end{array}$ & $\begin{array}{l}1.30^{\mathrm{a}} \\
0.52^{\mathrm{b}} \\
0.42^{\mathrm{b}}\end{array}$ & $\begin{array}{l}0.076^{\mathrm{a}} \\
0.033^{\mathrm{b}} \\
0.027^{\mathrm{b}}\end{array}$ & $\begin{array}{l}0.039^{\mathrm{a}} \\
0.030^{\mathrm{ab}} \\
0.024^{\mathrm{b}}\end{array}$ & $\begin{array}{l}2.87^{\mathrm{a}} \\
2.97^{\mathrm{a}} \\
3.19^{\mathrm{b}}\end{array}$ & $\begin{array}{l}0.0068^{\mathrm{a}} \\
0.0044^{\mathrm{b}} \\
0.0036^{\mathrm{bc}}\end{array}$ & $\begin{array}{l}5.7^{\mathrm{a}} \\
6.8^{\mathrm{b}} \\
7.1^{\mathrm{b}}\end{array}$ & $\begin{array}{l}320^{\mathrm{a}} \\
143^{\mathrm{b}} \\
140^{\mathrm{b}}\end{array}$ \\
\hline South & $\begin{array}{l}0-4.5 \\
7.5-12.0 \\
15-19.5\end{array}$ & $\begin{array}{l}1.36^{\mathrm{a}} \\
1.48^{\mathrm{b}} \\
1.53^{\mathrm{b}}\end{array}$ & $\begin{array}{l}1.22^{\mathrm{a}} \\
0.50^{\mathrm{b}} \\
0.38^{\mathrm{b}}\end{array}$ & $\begin{array}{l}0.074^{a} \\
0.032^{b} \\
0.026^{b}\end{array}$ & $\begin{array}{l}0.033^{\mathrm{ab}} \\
0.029^{\mathrm{ab}} \\
0.027^{\mathrm{ab}}\end{array}$ & $\begin{array}{l}2.96^{\mathrm{a}} \\
3.00^{\mathrm{a}} \\
2.93^{\mathrm{a}}\end{array}$ & $\begin{array}{l}0.0077^{\mathrm{a}} \\
0.0042^{\mathrm{b}} \\
0.0033^{\mathrm{bc}}\end{array}$ & $\begin{array}{l}6.0^{\mathrm{a}} \\
6.7^{\mathrm{b}} \\
6.8^{\mathrm{b}}\end{array}$ & $\begin{array}{l}192^{\mathrm{b}} \\
139^{\mathrm{b}} \\
163^{\mathrm{b}}\end{array}$ \\
\hline Open & $\begin{array}{l}0-4.5 \\
7.5-12.0 \\
15-19.5 \\
\end{array}$ & $\begin{array}{l}1.57^{\mathrm{b}} \\
1.54^{\mathrm{b}} \\
1.54^{\mathrm{b}}\end{array}$ & $\begin{array}{l}0.43^{\mathrm{b}} \\
0.36^{\mathrm{b}} \\
0.39^{\mathrm{b}}\end{array}$ & $\begin{array}{l}0.027^{b} \\
0.024^{b} \\
0.022^{b}\end{array}$ & $\begin{array}{l}0.030^{\mathrm{ab}} \\
0.029^{\mathrm{ab}} \\
0.030^{\mathrm{ab}}\end{array}$ & $\begin{array}{l}2.94^{\mathrm{a}} \\
3.02^{\mathrm{a}} \\
2.97^{\mathrm{a}}\end{array}$ & $\begin{array}{l}0.0026^{\mathrm{c}} \\
0.0028^{\mathrm{c}} \\
0.0024^{\mathrm{c}}\end{array}$ & $\begin{array}{l}6.0^{\mathrm{a}} \\
6.8^{\mathrm{b}} \\
7.0^{\mathrm{b}}\end{array}$ & $\begin{array}{l}106^{\mathrm{c}} \\
110^{\mathrm{bc}} \\
114^{\mathrm{bc}}\end{array}$ \\
\hline
\end{tabular}

${ }^{1}$ Values compared among depths at an individual location and across locations at the same depth, without one or more common letters, are significantly different at the $95 \%$ level. 
species, and thus would not exhibit as strong an acidifying effect as litter of the 45-year-old shore pine studicd by Zinke (1962).

The differential accumulation of litter between north and south sides of the trees is probably responsible for higher soluble salts in the surface layer, and the observed distribution pattern of $\mathrm{K}$ and $\mathbf{P}$ with soil depth on the north side of the trees. Potassium is readily leached from plant materials and can be expected to leach downward more readily where the ratio of soluble salts to cation-exchange capcity is higher (Black, 1968). This situation is more likely to occur on the north than the south side of mesquite trees. Moreover, from the standpoint of total water movement, the opportunity for leaching appears better on the north side of trees.

The distribution of $\mathrm{P}$ with depth on the north side of mesquite trees is opposite that of $K$ (i.e., amount of $P$ declines with depth). This can be expected as the phosphate ion is relatively immobile and is not likely to move rapidly downward from the point of accrual to the soil. Differences between soil layers are more likely to occur on the north side of trees where accrual of P via litter fall is greater. The expected higher accruals of $\mathrm{P}$ on the north side of mesquite trees seem to be showing up in a trend toward differences between locations even though the differences are not yet significant.

Data presented in this paper demonstrate a definite distribution pattern of soil properties within the zone of influence of mesquite trees. There is a strong indication that the mesquite trees are the causal agent of the patterns observed and that they function to improve soil conditions beneath their canopies at the expense of soil between the trees. The improved soil conditions coupled with higher availability of nutrients under the mesquite canopy (Tiedemann and Klemmedson, 1970) and demonstrated ability of some perennial grasses to adapt to shade in the desert grassland (Tiedemann et al., 1971) explains the abundance and improved growth of perennial grasses observed under mesquite (Humphrey, 1962; Tiedemann, 1970). In some situations, particularly on ranges which have had poor grazing management, perennial grasses may not be abundant under mesquite. Our observations indicate that cattle seek out the more palatable forage under mesquite trees on the desert grassland. Unless this use is controlled, the perennials probably lose vigor rapidly and eventually succumb. Despite ability to adapt to shade under the conditions of improved soil fertility, the grasses growing under mesquite are probably more vulnerable to grazing pressure, especially from the standpoint of root growth and total carbohydrates, than grasses growing in unshaded conditions.

\section{Literature Cited}

Belt, C. B., Jr. 1967. Partial analysis of silicate rocks by atomic absorption. Anal. Chem. 39:676-678.

Black, C. A., D. D. Evans, J. L. White, and others. 1965a. Methods of soil analysis. Part I, Agronomy No. 9, Amer. Soc. Agron. and Amer. Soc. Testing Mater., Madison, Wis. $770 \mathrm{p}$.

Black, C. A., D. D. Evans, J. L. White, and others. 1965b. Methods of soil analysis. Part
2, Agronomy No. 9, Amer. Soc. Agron. and Amer. Soc. Testing Mater., Madison, Wis. $802 \mathrm{p}$.

Black, Charles A. 1968. Soil-plant relationships, 2nd ed. John Wiley and Sons, Inc., New York. $792 \mathrm{p}$.

Garcia-Moya, Edmundo, and Cyrus M. McKell. 1970. Contribution of shrubs to the nitrogen economy of a desert wash plant community. Ecology 51:81-88.

Fireman, M., and H. E. Hayward. 1952. Indicator significance of some shrubs in the Escalante Desert, Utah. Bot. Gaz. 114:143-155.

Humphrey, Robert R. 1962. Range ecology. Ronald Press Co., New York. 234 p.

Jenny, Hans. 1941. Factors of soil formation. McGraw-Hill Book Co., Inc., New York. 281 p.

Kearney, Thomas Henry, and R. H. Peebles. 1960. Arizona flora. 2nd ed. Univ. Calif. Press, Berkeley. 1085 p.

Parker, Kenneth W., and S. Clark Martin. 1952. The mesquite problem on southern Arizona ranges. U. S. Dep. Agr. Circ. No. 908.70 p.

Paulsen, Harold A. 1950. A comparison of surface soil properties under mesquite and perennial grass. Ecology 34:727-732.

Tiedemann, Arthur R. 1970. Effect of mesquite (Prosopis juliflora) trees on herbaceous vegetation and soils in the desert grassland. Unpublished Ph.D. thesis, Univ. Ariz., Tucson, $159 \mathrm{p}$.

Tiedemann, Arthur R., and Tom D. Anderson. 1971. Rapid analysis of total sulphur in soils and plant material. Plant and Soil 35(1): 197-200.

Tiedemann, Arthur R., and James O. Klemmedson. 1970. Nutrient availability in desert grassland soils under mesquite (Prosopis juliflora) trees and adjacent open areas. Agron. Abstr. 1970:163-164.

Tiedemann, Arthur R., James O. Klemmedson, and Phil R. Ogden. 1971. Response of four perennial southwestern grasses to shade. J. Range Manage. 24:442-447.

Zinke, Paul J. 1962. The pattern of influence of individual trees on soil properties. Ecology 43:130-133.

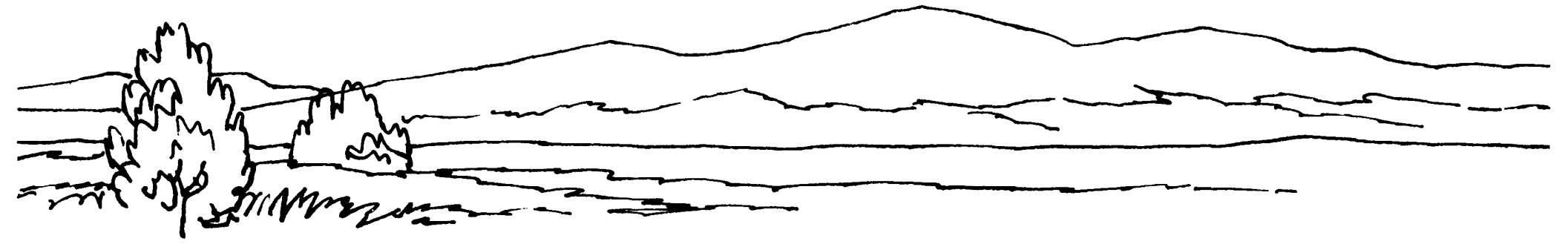

